\title{
Pseudomonas libanensis sp. nov., a new species isolated from Lebanese spring waters
}

\author{
F. Dabboussi, ${ }^{1}$ M. Hamze, ${ }^{2}$ M. Elomari, ${ }^{1}$ S. Verhille, ${ }^{1}$ N. Baida, ${ }^{1}$ D. Izard ${ }^{1}$ \\ and $\mathrm{H}$. Leclerc'
}

Author for correspondence: H. Leclerc. Tel: +3303205294 28. Fax: +330320529361. e-mail: leclerc@univ-lille2.fr

\author{
1 Laboratoire de \\ Bactériologie-Hygiène, \\ Faculté de Médecine Henri \\ Warembourg, (Pôle \\ Recherche), 1 Place de \\ Verdun, 59045 Lille, France \\ 2 Faculté de Santé Publique, \\ Section 3, Université \\ Libanaise \& CNRS Liban, \\ France
}

\begin{abstract}
The taxonomic position of eight fluorescent Pseudomonas isolates, from two Lebanese spring waters, which were previously recognized by numerical analysis as members of a new subcluster (subcluster Vb) was examined. Except for one strain, the new subcluster exhibited internal DNA hybridization values of 76-100\%, and 9-53\% hybridization was measured with the type or reference strains of other Pseudomonas species. The highest DNA binding value was found with Pseudomonas marginalis strains (37-53\%). The G+C content of the DNA of the type strain was $58 \mathrm{~mol} \%$. A comparison of $1322 \mathrm{nt}$ of the 165 rRNA gene sequence of the strain representing subcluster Vb (CFML 96-195') with the sequence of other strains of the genus Pseudomonas revealed that strain CFML 96-195' was part of the 'Pseudomonas fluorescens intrageneric cluster'. On the basis of the results of phenotypic, DNA-DNA and phylogenetic analyses, a new Pseudomonas species, Pseudomonas libanensis sp. nov., is proposed for the seven strains of subcluster $\mathrm{Vb}$. The type strain is $P$. libanensis CFML 96-195' and has been deposited in the Collection de l'Institut Pasteur (Paris, France) as CIP 105460'. The P. libanensis strains are phenotypically and genotypically homogeneous and can be differentiated from most other fluorescent species by several phenotypic features. Differentiation of $\boldsymbol{P}$. libanensis and Pseudomonas aeruginosa is based mainly on pyocyanin production; $P$. libanensis can be differentiated from $P$. fluorescens (all biovars) by $\alpha$-aminobutyrate assimilation. The clinical significance of $P$. libanensis is unknown.
\end{abstract}

Keywords: Pseudomonas libanensis sp. nov., DNA-DNA hybridization, 16S rRNA

\section{INTRODUCTION}

The aerobic pseudomonads are bacteria of considerable scientific and practical importance; they are widespread in nature and are being isolated in increasing numbers and kind. Fluorescent Pseudomonas strains constitute a diverse group of bacteria that can generally be visually distinguished from other pseudomonads by their ability to produce a water-soluble yellow-green pigment. On the basis of DNA-rRNA hybridization, Palleroni et al. (1973) have enabled subdivision of the genus Pseudomonas into five homology groups. Sequence analysis of the $16 \mathrm{~S}$ rRNA gene has provided a clear framework for the systematic grouping of the five homology groups. It is now

The EMBL accession number for the 16S rRNA gene sequence of strain CFML $96-195^{\top}$ is AF057645. generally recognized that the genus Pseudomonas sensu stricto should be limited to those organisms clustering in DNA-rRNA homology group I (De Vos \& De Ley, 1983 ) in the $\gamma$-subclass of the Proteobacteria (Woese, 1987). Many organisms originally described as species of the genus Pseudomonas have been reclassified in other genera and families (De Vos et al., 1985; Gillis et al., 1995; Palleroni \& Bradbury, 1993; Segers et al., 1994; Swings et al., 1983; Urakami et al., 1994; Willems et al., 1989, 1990, 1991, 1992; Yabuuchi et al., 1992, 1995). The genus Pseudomonas sensu stricto includes both fluorescent and non-fluorescent species (Pseudomonas stutzeri, Pseudomonas mendocina, Pseudomonas alcaligenes and Pseudomonas fragi). The saprophitic fluorescent pseudomonads are characterized by the production of water-soluble pigments (pyoverdins) and can be distinguished from phytopathogenic species by their positive arginine dihy- 
Table 1. Levels of DNA-DNA hybridization of labelled strain CFML $96-195^{\top}$ with phenotypic clusters or subclusters

CFML, Collection de la Faculté de Médecine de Lille, Lille, France; NC, strain not belonging to any cluster. All strains were isolated from three Lebanese spring waters, A, B and C (Kadicha, Kassam and Mar-Sarkis, respectively) at the point of emergence. RBR, Relative binding ratio of DNAs.

\begin{tabular}{|c|c|c|c|c|c|}
\hline \multirow[t]{2}{*}{$\begin{array}{l}\text { Phenotypic cluster } \\
\text { or subcluster }\end{array}$} & \multirow[t]{2}{*}{ Strain (CFML no.) } & \multirow[t]{2}{*}{$\begin{array}{l}\text { Origin of } \\
\text { spring water }\end{array}$} & \multicolumn{2}{|c|}{$\begin{array}{l}\text { Labelled DNA from } \\
\text { strain CFML 96-195 }\end{array}$} & \multirow[t]{2}{*}{$\mathrm{G}+\mathrm{C}$ content $(\mathrm{mol} \%)$} \\
\hline & & & RBR (\%) & $\Delta T_{\mathrm{m}}\left({ }^{\circ} \mathrm{C}\right)$ & \\
\hline \multirow[t]{8}{*}{$\mathrm{Vb}$} & $96-195^{\mathrm{T}}$ & A & 100 & 0 & 58 \\
\hline & $96-172$ & $\mathrm{C}$ & 95 & & \\
\hline & $96-194$ & A & 95 & & 59 \\
\hline & $96-193$ & A & 94 & & \\
\hline & $96-199$ & A & 85 & & \\
\hline & $96-192$ & A & 84 & 1 & \\
\hline & $96-183$ & A & 76 & 1 & 58 \\
\hline & $96-210$ & A & 61 & 8 & \\
\hline \multirow[t]{3}{*}{ Ia } & $96-217$ & A & 30 & & \\
\hline & $96-197$ & A & 43 & & \\
\hline & $96-171$ & $\mathrm{C}$ & 46 & & \\
\hline \multirow[t]{6}{*}{ II } & $96-201$ & $\mathrm{~A}$ & 36 & & \\
\hline & $96-169$ & B & 43 & & \\
\hline & $96-219$ & $\mathrm{~A}$ & 40 & & \\
\hline & $96-184$ & A & 42 & & \\
\hline & $96-216$ & A & 48 & & \\
\hline & $96-190$ & A & 40 & & \\
\hline \multirow[t]{2}{*}{ IVa } & $96-200$ & A & 52 & 8 & \\
\hline & $96-196$ & A & 48 & & \\
\hline \multirow[t]{3}{*}{ Va } & $96-186$ & A & 47 & & \\
\hline & $96-205$ & A & 46 & & \\
\hline & $96-175$ & $\mathrm{C}$ & 40 & & \\
\hline \multirow[t]{3}{*}{$\mathrm{Vc}$} & $96-173$ & C & 41 & & \\
\hline & $96-180$ & A & 45 & & \\
\hline & $96-211$ & A & 47 & & \\
\hline \multirow[t]{7}{*}{$\mathrm{Vd}$} & $96-170$ & B & 61 & 8 & \\
\hline & $96-164$ & B & 50 & 9 & \\
\hline & $96-167$ & B & 56 & 9 & \\
\hline & $96-178$ & $\mathrm{C}$ & 54 & 9 & \\
\hline & $96-166$ & B & 50 & 9 & \\
\hline & $96-181$ & A & 41 & & \\
\hline & $96-188$ & A & 67 & 7 & \\
\hline \multirow[t]{9}{*}{$\mathrm{Ve}$} & $96-179$ & $\mathrm{C}$ & 49 & & \\
\hline & $96-215$ & A & 51 & 9 & \\
\hline & $96-209$ & A & 53 & 9 & \\
\hline & $96-176$ & C & 52 & 9 & \\
\hline & $96-214$ & A & 60 & 8 & \\
\hline & $96-213$ & A & 58 & 9 & \\
\hline & $96-174$ & $\mathrm{C}$ & 54 & 9 & \\
\hline & $96-163$ & B & 41 & & \\
\hline & $96-198$ & A & 56 & 9 & \\
\hline \multirow[t]{8}{*}{ Vf } & $96-206$ & A & 43 & & \\
\hline & $96-189$ & A & 41 & & \\
\hline & $96-204$ & A & 44 & & \\
\hline & $96-177$ & $\mathrm{C}$ & 48 & & \\
\hline & $96-207$ & A & 39 & & \\
\hline & $96-185$ & A & 43 & & \\
\hline & $96-191$ & A & 39 & & \\
\hline & $96-182$ & A & 37 & & \\
\hline
\end{tabular}


Table 1. (cont.)

\begin{tabular}{|c|c|c|c|c|c|}
\hline \multirow[t]{2}{*}{$\begin{array}{l}\text { Phenotypic cluster } \\
\text { or subcluster }\end{array}$} & \multirow[t]{2}{*}{ Strain (CFML no.) } & \multirow[t]{2}{*}{$\begin{array}{l}\text { Origin of } \\
\text { spring water }\end{array}$} & \multicolumn{2}{|c|}{$\begin{array}{l}\text { Labelled DNA from } \\
\text { strain CFML 96-195 }\end{array}$} & \multirow[t]{2}{*}{$\mathrm{G}+\mathrm{C}$ content $(\mathrm{mol} \%)$} \\
\hline & & & RBR (\%) & $\Delta T_{m}\left({ }^{\circ} \mathrm{C}\right)$ & \\
\hline \multirow[t]{2}{*}{$\mathrm{Vg}$} & $96-212$ & A & 47 & & \\
\hline & $96-203$ & A & 43 & & \\
\hline \multirow[t]{3}{*}{ VI } & $96-187$ & A & 46 & & \\
\hline & $96-218$ & A & 53 & 8 & \\
\hline & $96-208$ & A & 44 & & \\
\hline \multirow[t]{3}{*}{ VIIIa } & $96-165$ & B & 35 & & \\
\hline & $96-202$ & A & 40 & & \\
\hline & $96-162$ & B & 18 & & \\
\hline $\mathrm{NC}$ & $96-168$ & B & 24 & & \\
\hline
\end{tabular}

drolase reaction. The complexity of fluorescent saprophyte species other than Pseudomonas aeruginosa (considered a homogeneous species; Palleroni, 1984) has been well illustrated by extensive studies (Barrett et al., 1986; Champion et al., 1980; Molin \& Ternström 1982; Palleroni et al., 1973; Elomari et al., 1997).

Nevertheless, pseudomonad identification at the species level continues to be a difficult task, especially in environmental studies where this group is a majority, such as aquatic ecosystems. Natural waters can be characterized by their bacterial flora which is considered to be an indicator of the quality of the water. Leclerc \& Guillot (1992) showed that approximately $80 \%$ of strains isolated from natural waters were not identifiable at the species level and that the majority of strains which could be identified were fluorescent members of the genus Pseudomonas. These results have revealed the need to greatly improve our understanding of fluorescent pseudomonads in the natural environment.

In a previous study (Dabboussi et al., 1998) we performed a numerical analysis with 58 isolates. These were isolated at the point of emergence of three important spring waters in North Lebanon that feed $45 \%$ of the Lebanese population (Kadicha, Kassam and Mar-Sarkis). These isolates were identified as fluorescent pseudomonads. This numerical analysis indicated the presence of three phenotypic subclusters ( $\mathrm{Vb}, \mathrm{Vd}$ and $\mathrm{Ve}$ ), including strains found only in Lebanese spring water. This paper describes the phenotypic, genotypic (DNA-DNA hybridization, $\Delta T_{\mathrm{m}}, \mathrm{G}+\mathrm{C}$ content) and phylogenetic (16S rDNA sequence analysis) properties of subcluster $\mathrm{Vb}$ (Dabboussi et al., 1998) and proposes a new species, Pseudomonas libanensis sp. nov., for seven strains of this subcluster. The type strain (CFML 96-195') has been deposited in the Collection de l'Institut Pasteur (Paris, France) as CIP $105460^{\mathrm{T}}$.

\section{METHODS}

Bacterial strains. A total of 121 strains were used in this study: 58 wild strains, previously listed in detail (Dabboussi et al., 1998), isolated from three Lebanese spring waters (Table 1) and 65 reference strains used in DNA-DNA hybridizations and representing 24 known species of the genus Pseudomonas sensu stricto (Kersters et al., 1996) and three newly described Pseudomonas species, Pseudomonas veronii (Elomari et al., 1996), Pseudomonas rhodesiae (Coroler et al., 1996), both isolated from French mineral waters, and Pseudomonas monteilii (Elomari et al., 1997) isolated from clinical specimens (Table 2). All bacteria were cultured routinely on Mueller-Hinton medium at $30^{\circ} \mathrm{C}$.

Biochemical, physiological and flagellar characteristics. Phenotypic data for the 121 strains used in this study have been described previously (Dabboussi et al., 1998). The flagellation of the bacteria was investigated by electron microscopy using a negative-staining technique (Hoeniger, 1965) on fixed organisms. The stained bacteria were examined with a JEOL type $100 \mathrm{CX}$ transmission electron microscope.

DNA extraction and purification. Chromosomal DNA was isolated and purified according to the method of Beji et al. (1987).

DNA base composition. The $\mathrm{G}+\mathrm{C}$ content of DNA was determined from the mid-point value of the thermal denaturation profile. The $\mathrm{G}+\mathrm{C}$ content was calculated by using the equation of De Ley (1970) and Escherichia coli ATCC $11775^{\mathrm{T}}$ DNA was used as reference $(\mathrm{G}+\mathrm{C}$ content $51 \mathrm{~mol} \%$ ).

DNA-DNA similarity. DNA-DNA hybridization tests were carried out by using labelled DNAs from strain CFML 96$195^{\mathrm{T}}$ (subcluster Vb; Dabboussi et al., 1998). Native DNA was labelled in vitro by nick translation with tritium-labelled nucleotides. The S1 nuclease-trichloroacetic acid method used for hybridization has been described by Crosa et al. (1973) and Grimont et al. (1980). The reaction mixture of radioactively labelled DNA and unlabelled DNA was incubated for $16 \mathrm{~h}$ at $60^{\circ} \mathrm{C}$. 
Table 2. Levels of DNA relatedness of $P$. libanensis to different type and collection strains of the genus Pseudomonas RBR, Relative binding ratio of DNAs.

\begin{tabular}{|c|c|c|c|c|}
\hline \multirow[t]{2}{*}{ Source of unlabelled DNA* } & \multicolumn{2}{|c|}{$\begin{array}{c}\text { Labelled DNA from } \\
\text { strain CFML } \\
9^{96-195}\end{array}$} & \multirow[t]{2}{*}{ Source of unlabelled DNA* } & $\begin{array}{c}\text { Labelled DNA from } \\
\text { strain CFML } \\
96-195^{T}\end{array}$ \\
\hline & $\operatorname{RBR}(\%)$ & $\Delta T_{\mathrm{m}}\left({ }^{\circ} \mathrm{C}\right)$ & & $\operatorname{RBR}(\%) \Delta T_{\mathrm{m}}\left({ }^{\circ} \mathrm{C}\right)$ \\
\hline$P$. aeruginosa ATCC $10145^{\mathrm{T}}$ & 15 & & P. mucidolens CIP $103298^{\mathrm{T}}$ & 42 \\
\hline P. aeruginosa ATCC 27853 & 25 & & & \\
\hline \multirow[t]{2}{*}{ P. aeruginosa ATCC 15692} & 20 & & P. lundensis CCM 573 & 14 \\
\hline & & & P. lundensis CCUG 18785 & 20 \\
\hline P. fluorescens biovar I ATCC $13525^{\mathrm{T}}$ & 50 & 8 & & \\
\hline P. fluorescens biovar I ATCC 17563 & 51 & 6 & P. syringae ATCC $19310^{\mathrm{T}}$ & 15 \\
\hline P. fluorescens biovar II ATCC 17816 & 43 & & & \\
\hline P. fluorescens biovar II ATCC 17815 & 41 & & P. savastanoi CFBP $1670^{\mathrm{T}}$ & 22 \\
\hline P. fluorescens biovar II ATCC 17482 & 44 & & P. savastanoi CFBP 2088 & 26 \\
\hline P. fluorescens biovar II DSM 50106 & 38 & & P. savastanoi CFBP 1838 & 17 \\
\hline P. fluorescens biovar III ATCC 17559 & 38 & & & \\
\hline P. fluorescens biovar III ATCC 17400 & 40 & & $P$. viridiflava ATCC $13223^{\mathrm{T}}$ & 21 \\
\hline P. fluorescens biovar III ATCC 17571 & 43 & & & \\
\hline P. fluorescens biovar IV DSM 50415 & 35 & & P. cichorii DSM $50259^{\mathrm{T}}$ & 14 \\
\hline P. fluorescens biovar IV ATCC 12983 & 30 & & & \\
\hline P. fluorescens biovar V ATCC 14150 & 45 & & $P$. agarici ATCC $25941^{\mathrm{T}}$ & 28 \\
\hline P. fluorescens biovar V ATCC 17518 & 50 & 7 & & \\
\hline P. fluorescens biovar V ATCC 15916 & 51 & 6 & P. asplenii ATCC $23835^{\mathrm{T}}$ & 25 \\
\hline P. fluorescens biovar V ATCC 17386 & 34 & & & \\
\hline P. fluorescens biovar V ATCC 17573 & 23 & & P. caricapapayae NCPPB $1873^{\mathrm{T}}$ & 17 \\
\hline \multirow[t]{2}{*}{ P. fluorescens biovar V DSM 50148} & 25 & & & \\
\hline & & & P. tolaasii NCPPB $2129^{\mathrm{T}}$ & 23 \\
\hline P. marginalis ATCC $10844^{\mathrm{T}}$ & 40 & & P. tolaasii NCPPB 1616 & 43 \\
\hline P. marginalis DSM 50275 & 53 & 8 & & \\
\hline \multirow[t]{2}{*}{ P. marginalis DSM 50276} & 37 & & P. stutzeri ATCC $17588^{\mathrm{T}}$ & 33 \\
\hline & & & P. stutzeri ATCC 17591 & 11 \\
\hline P. chlororaphis DSM 50083 & 25 & & P. stutzeri ATCC 17587 & 20 \\
\hline P. chlororaphis ATCC 9447 & 35 & & P. stutzeri ATCC 17686 & 16 \\
\hline \multirow[t]{2}{*}{ P. chlororaphis ATCC 17414} & 35 & & & \\
\hline & & & P. mendocina ATCC $25411^{\mathrm{T}}$ & 13 \\
\hline P. aureofaciens CCEB $518^{\mathrm{T}}$ & 45 & & P. mendocina ATCC 25412 & 18 \\
\hline \multirow[t]{2}{*}{ P. aureofaciens ATCC 17415} & 40 & & & \\
\hline & & & $P$. alcaligenes ATCC $14909^{\mathrm{T}}$ & 14 \\
\hline \multirow[t]{2}{*}{ P. veronii $\mathrm{CIP} 104663^{\mathrm{T}}$} & 42 & & & \\
\hline & & & P. pseudoalcaligenes ATCC $17440^{\mathrm{T}}$ & 15 \\
\hline P. rhodesiae CIP $104664^{\mathrm{T}}$ & 43 & & P. pseudoalcaligenes ATCC 12815 & 18 \\
\hline P. putida biovar A ATCC $12633^{\mathrm{T}}$ & 16 & & P. fragi ATCC $4973^{\mathrm{T}}$ & 22 \\
\hline P. putida biovar A DSM 50208 & 26 & & P. fragi ATCC 27362 & 26 \\
\hline P. putida biovar B ATCC 17484 & 31 & & & \\
\hline P. putida biovar B ATCC 17430 & 23 & & P. flavescens NCPPB $3063^{\mathrm{T}}$ & 25 \\
\hline P. putida biovar B CCUG 1317 & 25 & & P. flavescens CIP 104205 & 19 \\
\hline P. monteilii CIP $104883^{\mathrm{T}}$ & 9 & & P. fuscovaginae NCPPB $3085^{\mathrm{T}}$ & 23 \\
\hline P. synxantha CIP $5922^{\mathrm{T}}$ & 49 & & & \\
\hline
\end{tabular}

* ATCC, American Type Culture Collection, Manassas, VA, USA; CCEB, Culture Collection of Entomogenous Bacteria, Institute of Entomology, Czechoslovakia Academy of Sciences, Prague, Czech Republic; CCM, Czechoslovak Collection of Microorganisms, F. E. Purkyne University of Brno, Brno, Czech Republic; CCUG, Culture Collection, University of Göteborg, Göteborg, Sweden; CFBP, Collection Française de Bactéries Phytopathogènes, Station de Pathologie Végétale et Phytobactériologie, Institut National de la Recherche Agronomique, Beaucouzé, France; CIP, Collection de l'Institut Pasteur, Paris, France; DSM, Deutsche Sammlung von Mikroorganismen und Zellkulturen $\mathrm{GmbH}$, Braunschweig, Germany; NCIB, National Collection of Industrial Bacteria, Aberdeen, UK; NCPPB, National Collection of Plant-Pathogenic Bacteria, Plant Pathology Laboratory, Hatching Green, Harpenden, UK. 
Table 3. Strains used for the 165 rDNA sequence analysis

\begin{tabular}{|c|c|c|}
\hline Species & Strain* & $\begin{array}{c}\text { EMBL } \\
\text { accession no. }\end{array}$ \\
\hline P. libanensis & CIP $105460^{T}$ & AF057645 \\
\hline$P$. aeruginosa & DSM $50071^{T}$ & X06684 \\
\hline$P$. agarici & LMG $2112^{\mathrm{T}}$ & Z76652 \\
\hline$P$. alcaligenes & LMG $1224^{\mathrm{T}}$ & Z76653 \\
\hline$P$. amygdali & LMG $2123^{\mathrm{T}}$ & Z76654 \\
\hline P. asplenii & LMG $2137^{\mathrm{T}}$ & Z76655 \\
\hline P. aureofaciens & DSM $6698^{\mathrm{T}}$ & Z76656 \\
\hline P. balearica & DSM $6083^{\mathrm{T}}$ & U26418 \\
\hline P. caricapapayae & $\operatorname{ATCC} 33615^{\mathrm{T}}$ & D84010 \\
\hline P. chlororaphis & IAM $12354^{\mathrm{T}}$ & D84011 \\
\hline P. cichorii & LMG $2162^{\mathrm{T}}$ & Z76658 \\
\hline P. citronellolis & DSM $50332^{\mathrm{T}}$ & $Z 76659$ \\
\hline$P$. coronafaciens & LMG $13190^{T}$ & $Z 76660$ \\
\hline P. corrugata & ATCC $29736^{\mathrm{T}}$ & D84027 \\
\hline P. ficuserectae & LMG $5694^{\mathrm{T}}$ & Z76661 \\
\hline P. flavescens & NCPPB $3063^{T}$ & U01916 \\
\hline P. fluorescens biovar I & DSM $50090^{\mathrm{T}}$ & $Z 76662$ \\
\hline P. marginalis pv. marginalis & LMG $2210^{\mathrm{T}}$ & Z76663 \\
\hline P. mendocina & LMG $1223^{\mathrm{T}}$ & Z76664 \\
\hline P. monteilii & CIP $104883^{\mathrm{T}}$ & AF064458 \\
\hline P. mucidolens & IAM $12406^{T}$ & D84025 \\
\hline P. oleovorans & DSM $1045^{T}$ & $Z 76665$ \\
\hline P. putida biovar A & DSM $291^{\mathrm{T}}$ & Z76667 \\
\hline P. putida biovar B & ATCC 17472 & AF016428 \\
\hline P. pseudoalcaligenes & LMG $1225^{\mathrm{T}}$ & Z76666 \\
\hline$P$. resinovorans & LMG $2274^{\mathrm{T}}$ & Z76668 \\
\hline P. rhodesiae & CIP $104664^{T}$ & $Z 76669$ \\
\hline P. stutzeri & CCUG $11256^{\mathrm{T}}$ & U26262 \\
\hline P. synxantha & IAM $12356^{T}$ & AF064459 \\
\hline$P$. syringae & LMG $1247 \mathrm{t}^{\mathrm{T}}$ & D84017 \\
\hline P. taetrolens & IAM $1653^{T}$ & D84012 \\
\hline P. tolaasii & LMG $2342^{\mathrm{T}}$ & $\mathrm{Z} 76670$ \\
\hline P. veronii & CIP $104663^{\mathrm{T}}$ & AF064460 \\
\hline$P$. viridiflava & LMG $2352^{\mathrm{T}}$ & $\mathrm{Z} 76671$ \\
\hline
\end{tabular}

* IAM, Institute of Applied Microbiology, University of Tokyo, Tokyo, Japan; LMG, Laboratorium voor Microbiologie, Rijksuniversiteit Gent, Gent, Belgium; CIP, DSM, CCUG, NCPPB, ATCC, see Table 2.

Thermal stability of reassociated DNAs. The temperature at which $50 \%$ of reassociated DNA was hydrolysed by nuclease $\mathrm{S} 1\left(T_{\mathrm{m}}\right)$ was determined by using the method of Crosa et al. (1973). $\Delta T_{\mathrm{m}}$ is the difference between $T_{\mathrm{m}}$ of the heteroduplex and $T_{m}$ of the homoduplex.

165 rRNA gene sequence determination. The almost complete 16S rRNA gene sequence was determined for strain CFML $96-195^{\mathrm{T}}$ by direct PCR sequencing. DNA was amplified by using two $16 \mathrm{~S}$ rRNA universal primers, $\mathrm{pA}\left(5^{\prime}\right.$ AGAGTTTGATCCTGGCTCAG-3') and pH (5'-AAGGAGGTGATCCAGCCGCA-3'), which are complementary to $E$. coli $16 \mathrm{~S}$ rRNA positions 8-27 and 1544-1525, respectively (Brosius et al., 1978; Edwards et al., 1989; Lane, 1991). PCR amplification was performed by using a model 480 DNA thermal cycler (Perkin-Elmer) by using a PCR mixture (final vol. $100 \mu \mathrm{l}$ ) containing each of the four dNTPs at a concentration of $200 \mu \mathrm{M}$ each, primers pA and $\mathrm{pH}$ at a concentration of $1 \mathrm{mM}$ each, $1 \mu \mathrm{g}$ target DNA and $2.5 \mathrm{U}$ Taq DNA polymerase. The sequence of the PCRamplified 16S rRNA gene was determined directly using an Applied Biosystems 377 automated DNA sequencer, according to the protocols specified by the manufacturer, and the following primers: $\mathrm{pA}, \mathrm{pH}$ (used for amplification), primer 59-195 (5'-CTTATTCTGTCGGTAACGTC-3'), primer 21-195 (5'-GGGCTCAACCTGGGAACTGC-3'), primer 15-195 (5'-TCCACCGCTTGTGCGGGCCC-3') and primer 35-195 (5'-AGTTACCAGCCACGTCATGG-3'), covering the sequence at the following positions: 493-474, 608-627, 939-920 and $1116-1135$, respectively (E. coli numbering; Brosius et al., 1978).

Analysis of sequence data. The $16 \mathrm{~S}$ rRNA gene sequence that we determined and the sequences of other pseudomonad reference strains obtained from the EMBL database (Table 3) were aligned and analysed by using the CLUSTAL $X$ program (CLUSTAL $\mathrm{X}$ is a major rewrite of the multiple alignment program CLUSTAL w; Thompson et al., 1994). Nucleotide substitution rates ( $K_{\text {nuc }}$ values) were calculated (Kimura, 1980) and a phylogenetic tree was constructed by the neighbour-joining method of Saitou \& Nei (1987). An evaluation of the tree was carried out by using the bootstrap method (Felsenstein, 1985). A total of 1000 bootstrapped trees were generated. Calculations of levels of sequence similarity were based on the data for $1322 \mathrm{nt}$ because deleted and unknown positions were eliminated.

Nucleotide sequence accession numbers. The accession numbers of the sequences used for comparison with the sequence that we determined are shown in Table 3 .

\section{RESULTS}

\section{Phenotypic and flagellation characteristics}

Electron microscopic examination of strain CFML 96$195^{\mathrm{T}}$ showed that the cells were motile by a single polar flagellum (Fig. 1). The width of the cells was $0.5 \mu \mathrm{m}$

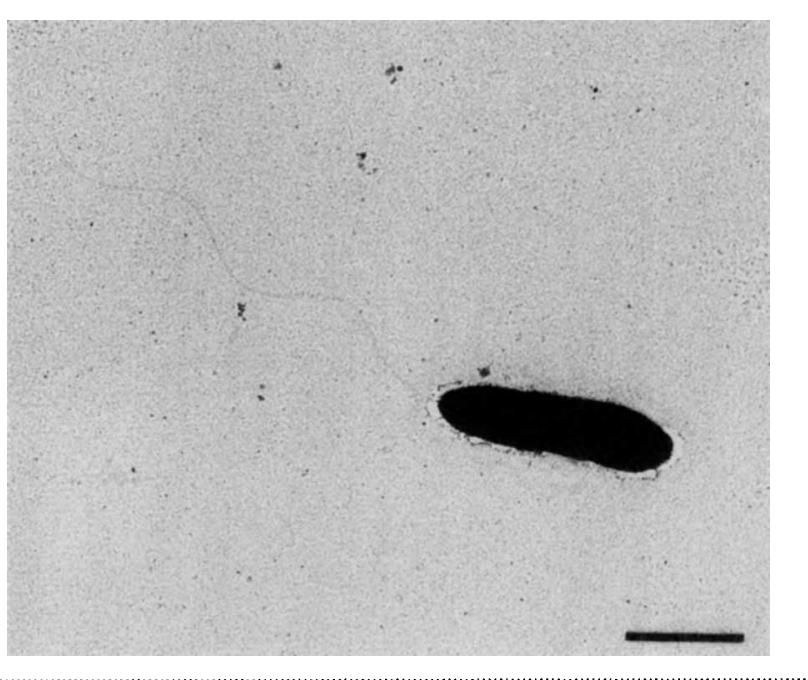

Fig. 1. Electron micrograph of a cell of $P$. libanensis CIP $105460^{\top}$ showing the single polar flagellum. Bar, $1 \mu \mathrm{m}$. 


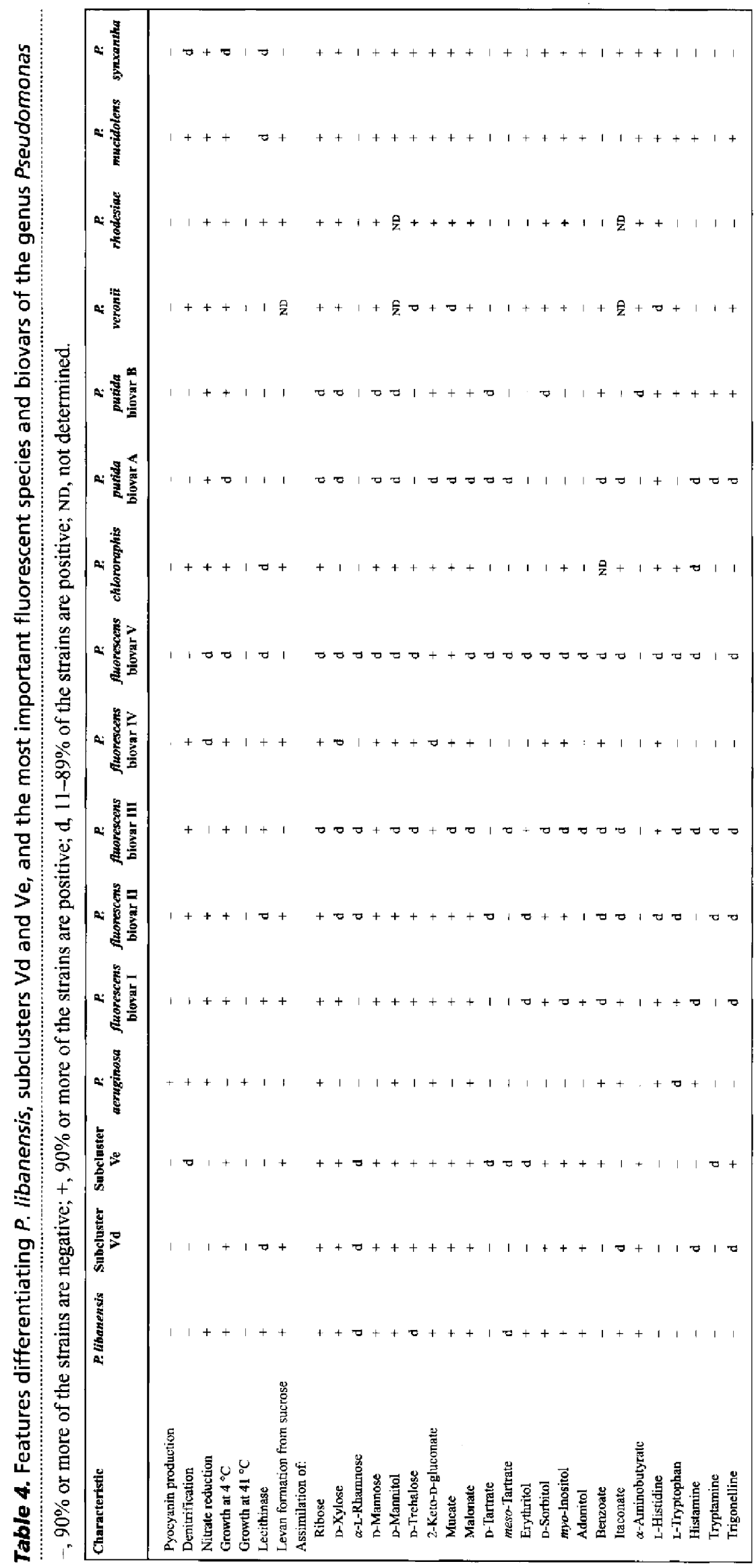


Table 5. Characteristics of the seven $P$. libanensis strains

+ , Positive; - , negative. The number in parentheses indicates the number of strains that deviated from the most common result. All the reactions of the type strain are the same as the reactions of other $P$. libanensis strains except for the presence of trypsin.

\begin{tabular}{|lcc|}
\hline Characteristic & $\begin{array}{c}\text { Seven } \boldsymbol{P} \text {. } \\
\text { libanensis } \\
\text { strains }\end{array}$ & $\begin{array}{c}\text { Type } \\
\text { strain }\end{array}$ \\
\hline Conventional tests & & \\
$\quad$ Urea & $+(1)$ & + \\
Carbon sources & & \\
$\quad$ D-Trehalose & $+(1)$ & + \\
meso-Tartrate & $-(1)$ & - \\
$N$-Acetyl-D-glucosamine & $+(2)$ & + \\
$\alpha-$-Lhhamnose & $-(1)$ & - \\
D-Lyxose & $-(1)$ & - \\
trans-Aconitate & $+(1)$ & + \\
Enzymic tests & & \\
Lipase C & & - \\
Naphthol AS-BI phosphohydrolase & $-(3)$ & - \\
Valine arylamidase & $+(3)$ & + \\
Trypsin & $+(2)$ & - \\
\hline
\end{tabular}

and the length was $1 \mu \mathrm{m}$. Phenotypic data (conventional, assimilation and enzymic tests) obtained for the seven strains of subcluster $\mathrm{Vb}$ are shown in Tables 4 and 5. Phenotypic tests, which proved useful for differentiating these strains from other Pseudomonas species and their biovars, are also listed in Table 4.

\section{DNA relatedness and thermal stability}

The results of DNA-DNA hybridizations obtained with labelled DNA of subcluster Vb strain CFML 96$195^{\mathrm{T}}$ are shown in Tables 1 and 2 . Hybridization values within subcluster $\mathrm{Vb}$ (8 strains) were $61-100 \%$. For the three lowest relatedness values $(61,76$ and $84 \%)$, the $\Delta T_{\mathrm{m}}$ values were 8,1 and $1^{\circ} \mathrm{C}$, respectively. Hybridization experiments were also performed between strain CFML $96-195^{\mathrm{T}}$ and all 50 strains of the other phenotypic clusters and subclusters described previously as containing isolates from Lebanese spring waters (Dabboussi et al., 1998); all values ranged from 18 to $67 \%$. The highest values were obtained with subclusters $\mathrm{Vd}$ and Ve. The $\Delta T_{\mathrm{m}}$ value varied between 6 and $9{ }^{\circ} \mathrm{C}$ (Table 1). The level of reassociation between strain CFML $96-195^{\mathrm{T}}$ and all of the reference strains of the genus Pseudomonas used in this study (65 strains) are shown in Table 2 . All values were less than $53 \%$ with $\Delta T_{\mathrm{m}}$ values ranging from 6 to $8^{\circ} \mathrm{C}$.

\section{DNA base composition}

The $\mathrm{G}+\mathrm{C}$ content of strains CFML 96-195 ${ }^{\mathrm{T}}$, CFML 96-194 and CFML 96-183 was 58, 59 and $58 \mathrm{~mol} \%$, respectively (Table 1$)$.

\section{5 rDNA sequence analysis}

The sequence of $1322 \mathrm{nt}$ of the 16S rDNA gene of strain CFML $96-195^{\mathrm{T}}$ was aligned to other sequences of all species of the genus Pseudomonas sensu stricto (Kersters et al., 1996) available from the database and with three newly described species: $P$. veronii (Elomari et al., 1996), $P$. rhodesiae (Coroler et al., 1996) and $P$. monteilii (Elomari et al., 1997). A tree constructed by the neighbour-joining method (Saitou \& Nei, 1987) showing phylogenetic relationships of strain CFML $96-195^{\mathrm{T}}$ is shown in Fig. 2.

The levels of nucleotide similarities for the 16S rDNA sequence of strain CFML $96-195^{\mathrm{T}}$ and other Pseudomonas species ranged from $94.3 \%$ (P. aeruginosa) to 99.5\% (Pseudomonas synxantha). Furthermore, the sequence similarities between strain CFML 96-195 and both strains CFML 96-170 (subcluster Vd) and CFML 96-198 (subcluster Ve) were 98.5 and 99.3\%, respectively. Our 16S rRNA sequence comparison confirmed that CFML $96-195^{\mathrm{T}}$ belongs to the genus Pseudomonas.

\section{DISCUSSION}

In this study, a total of eight Pseudomonas strains, grouped on the basis of a numerical analysis of phenotypic subcluster Vb (Dabboussi et al., 1998), were subjected to further polyphasic characterization to determine their taxonomic status within the genus Pseudomonas.

The $\mathrm{G}+\mathrm{C}$ content of strain CFML 96-195 $(58 \mathrm{~mol} \%)$ falls within the expected range for Pseudomonas (58-70 mol\%; Palleroni, 1984). The results of DNA-DNA hybridization experiments (when DNA of representative strain CFML $96-195^{\mathrm{T}}$ of subcluster $\mathrm{Vb}$ was labelled) demonstrate that seven strains of this subcluster constitute a separate DNA hybridization group (76-100\% hybridization). The current polyphasic species concept suggests only strains with approximately $70 \%$ or greater DNADNA relatedness and with a $\Delta T_{\mathrm{m}}$ value of $5^{\circ} \mathrm{C}$ or less constitute a single species (Wayne et al., 1987). Only one strain of phenotypic subcluster $\mathrm{Vb}$, strain CFML 96-210, had relative binding ratios of $61 \%$ with labelled DNA from strain CFML $96-195^{\mathrm{T}}$ and a $\Delta T_{\mathrm{m}}$ value of $8^{\circ} \mathrm{C}$. Therefore, this strain was expelled from the group. Furthermore, this strain was phenotypically distinguishable from other strains of subcluster $\mathrm{Vb}$, since only this strain was able to denitrify, to assimilate 5-aminovalerate and was positive for tetrathionate reductase. The high level of DNA-DNA relatedness between these seven strains is in agreement with the results of our phenotypic analysis which showed that they are closely related to each other. In contrast, strain CFML $96-195^{\mathrm{T}}$ did not exhibit specific affinity to any other Pseudomonas species since the determined similarity values between the DNA of this strain and the DNA of other Pseudomonas strains were in the range $9-53 \%$ with $\Delta T_{\mathrm{m}}$ values greater than $6^{\circ} \mathrm{C}$. 


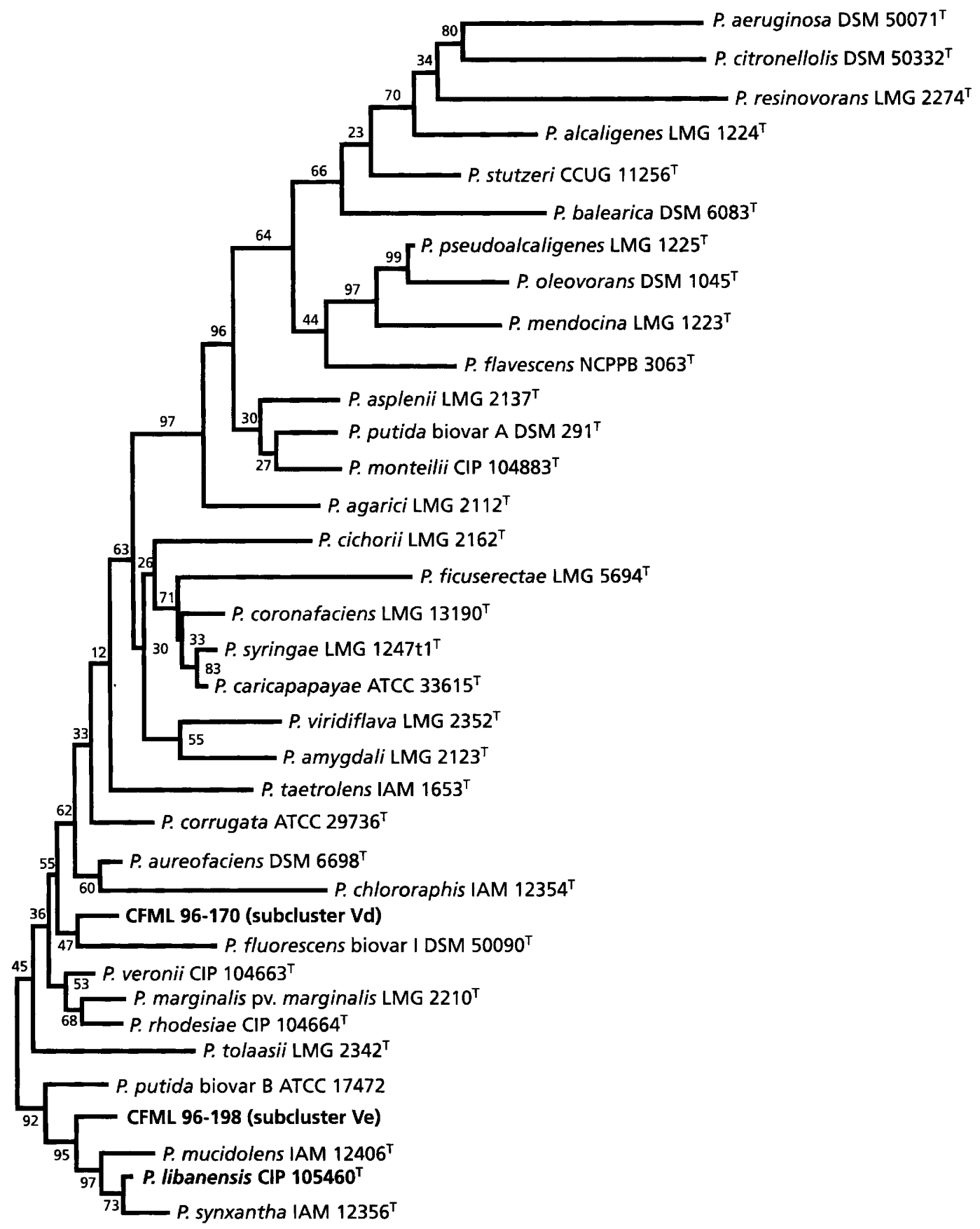

Fig. 2. Unrooted tree constructed by using the neighbour-joining method, showing the phylogenetic relationships of $P$. libanensis CIP $105460^{\top}$ and other species of the genus Pseudomonas sensu stricto. The numbers indicate the percentage occurrence in bootstrapped trees.

The highest hybridization values were obtained with biovars I and V of $P$. fluorescens $(51 \%)$ and with a representative strain of Pseudomonas marginalis (53\%). Moreover, DNA-DNA hybridization levels between strain CFML 96-195 ${ }^{\mathrm{T}}$ and subcluster Vd and Ve strains were rather high (41-67\%). In fact, strains of subcluster $\mathrm{Vb}$ (later named $P$. libanensis), $\mathrm{Vd}$ and $\mathrm{Ve}$ could be differentiated from each other by several phenotypic tests (Table 4). The derived 16S rRNA sequence of strain CFML $96-195^{\mathrm{T}}$ was aligned and compared with the sequences of strains CFML 96-170 and CFML 96-198 (subcluster Vd and Ve, respectively) and also with the sequences of other Pseudomonas species retrieved from the EMBL database. Strain CFML 96-195 ${ }^{\mathrm{T}}$ exhibited the lowest level of 16S rRNA sequence similarity with $P$. aeruginosa LMG $1242^{\mathrm{T}}(94 \cdot 3 \%)$. The highest level of sequence relatedness was observed with strain CFML 96-198 
(subcluster Ve) and with $P$. synxantha IAM $12356^{\mathrm{T}}$ ( 99.3 and $99.5 \%$, respectively), but these organisms could be differentiated by DNA-DNA hybridization data (Table 2) and several phenotypic features (Table 4). In fact, rDNA sequences probably do not always contain enough information to ascertain taxonomy at the species level and additional studies of phenotypes and DNA-DNA hybridization are therefore necessary (Boivin-Jahns et al., 1995; Wayne et al., 1987). The phylogenetic tree shows that strain CIP $105460^{\mathrm{T}}$ (= CFML 96-195 ${ }^{\mathrm{T}}$ ) falls within the radiation of the genus Pseudomonas and specifically within the 'Pseudomonas fluorescens intrageneric cluster' as defined by Moore et al. (1996). As a result of the polyphasic approach we propose a new species, Pseudomonas libanensis sp. nov., for the seven strains of subcluster $\mathrm{Vb}$. Affiliation to the genus Pseudomonas is justified by the close phylogenetic relationships of strain CFML $96-195^{\mathrm{T}}$ to other strains of this genus. The low level of DNADNA relatedness with other available Pseudomonas strains justifies the creation of a new species. $P$. libanensis strains are phenotypically and genotypically homogeneous and can be differentiated from related fluorescent members of the genus Pseudomonas by several phenotypic features (Table 4).

Differentiation of $P$. libanensis and $P$. aeruginosa is based on pyocyanin production, growth at $41^{\circ} \mathrm{C}$ and assimilation of D-mannitol, mucate, sorbitol, benzoate and histamine.

$P$. fluorescens species (all biovars) are mainly differentiated from $P$. libanensis by the assimilation of $\alpha-$ aminobutyrate. $P$. libanensis and Pseudomonas putida biovar B differ phenotypically since all strains of $P$. putida biovar B produce lecithinase and assimilate histidine, adonitol, myo-inositol and erythritol, whereas strains of $P$. libanensis are unable to utilize these compounds. Differentiation of $P$. libanensis and Pseudomonas mucidolens is based on denitrification ability and assimilation of trigonelline, histamine, tryptophan and itaconate.

$P$. synxantha is differentiated from $P$. libanensis by levan formation and assimilation of histidine and erythritol. Finally, nitrate reduction, lecithinase production and the assimilation of erythritol, itaconate, trigonelline and benzoate were found to differentiate $P$. libanensis strains from $\mathrm{Vd}$ and $\mathrm{Ve}$ subcluster strains (Table 4).

\section{Description of Pseudomonas libanensis sp. nov.}

Pseudomonas libanensis (li.ba.nen'sis. L. n. Libanus a mountain area in Southern Syria, Lebanon; L. adj. libanensis from or of Lebanon).

Motile by a single polar flagellum as observed by transmission electron microscopy of a cell of the type strain. Gram-negative. Cells produce a fluorescent pigment on King B medium, but not phenazine pigments on King A medium. Growth occurs between 4 and $36^{\circ} \mathrm{C}$ with optimal growth at $30^{\circ} \mathrm{C}$. Colonies on nutrient agar are smooth, circular and non-pigmented.
Poly- $\beta$-hydroxybutyrate is not accumulated as a carbon reserve material. Growth occurs in the presence of $3 \% \mathrm{NaCl}$ but not in the presence of $7 \% \mathrm{NaCl}$. All strains reduce nitrate to nitrite and grow on cetrimide. Non-haemolytic on blood agar. Negative for lipase, elastase and tetrathionate reductase. Arginine dihydrolase, lecithinase, catalase and cytochrome oxidase are produced. Cells are able to form levan from sucrose and can use citrate and malonate. Indole and coagulase are not produced. Lysine and ornithine are not decarboxylated. L-Tyrosine is hydrolysed but not aesculin. 2,3,5-Triphenyltetrazolium chloride is not used. Negative Voges-Proskauer reaction and tributyrin test. No action against DNA or RNA. All strains utilize the following substrates as carbon and energy sources: D-arabitol, myo-inositol, L-arabitol, xylitol, D-mannitol, D-sorbitol, adonitol, erythritol, Dmannose, ribose, D-galactose, L-arabinose, D-xylose, D-glucosamine, ethanolamine, D-saccharate, mucate, 2-ketogluconate, protocatechuate, $p$-hydroxybenzoate, 3-hydroxybutyrate, malonate, D-glucuronate, Dgalacturonate, itaconate and quinate. The following are not utilized as sole carbon and energy sources: maltitol, sucrose, $\alpha$-L-fucose, D-turanose, $\alpha$-D-melibiose, D-raffinose, maltotriose, maltose, D-cellobiose, $\beta$-gentiobiose, palatinose, $\mathrm{D}$-tagatose, $\alpha$-lactose, lactulose, 1- $O$-methyl- $\beta$-galactopyranoside, 1- $O$-methyl$\alpha$-galactopyranoside, 3- $O$-methyl-D-glycopyranose, 5keto-D-gluconate, tricarballylate, phenylacetate, gentisate, $m$-hydroxybenzoate, 5-aminovalerate, D-tartrate, benzoate, aesculin, trigonelline, histamine, tryptamine and inulin. All strains possess the following enzyme activities: alkaline phosphatase, acid phosphatase, esterase $\mathrm{C}_{4}$ and leucine arylamidase. None of the strains possess the following enzyme activities: $\alpha$ chymotrypsin, $\alpha$-galactosidase, $\beta$-galactosidase, $\beta$ glucoronidase, $\alpha$-glucosidase, $\alpha$-mannosidase and $\alpha$ fucosidase. Mean $\mathrm{G}+\mathrm{C}$ content of the type strain is $58 \mathrm{~mol} \%$. All strains were isolated from Lebanese spring waters. No clinical significance is known. Type strain is CFML $96-195^{\mathrm{T}}$, deposited in the Collection de l'Institut Pasteur as CIP $105460^{\mathrm{T}}$.

\section{REFERENCES}

Barrett, E. L., Solanes, R. E., Tang, J. S. \& Palleroni, N. J. (1986). Pseudomonas fluorescens biovar V: its resolution into distinct component groups and the relationship of these groups to other $P$. fluorescens biovars, to $P$. putida, and to psychrophilic pseudomonads associated with food spoilage. J Gen Microbiol 132, 2709-2721.

Beji, A., Izard, D., Gavini, F., Leclerc, H., Leseine-Delstanche, M. \& Krembel, J. (1987). A rapid chemical procedure for isolation and purification of chromosomal DNA from Gram-negative bacilli. Anal Biochem 161, 18-23.

Boivin-Jahns, V., Bianchi, A., Ruimy, R., Daumas, S. \& Christen, R. (1995). Comparison of phenotypical and molecular methods for the identification of bacterial strains isolated from a deep subsurface environment. Appl Environ Microbiol 61, 3400-3406.

Brosius, J., Palmer, M. L., Kennedy, P. J. \& Noller, H. F. (1978). Complete nucleotide sequence of a 16S ribosomal RNA gene from Escherichia coli. Proc Natl Acad Sci USA 75, 4801-4805. 
Champion, A. B., Barrett, E. L., Palleroni, N. J., Soderberg, R. L., Kunisawa, R., Contopoulou, R., Wilson, A. C. \& Doudoroff, M. (1980). Evolution in Pseudomonas fluorescens. J Gen Microbiol 120, 485-511.

Coroler, L., Elomari, M., Hoste, B., Gillis, M., Izard, D. \& Leclerc, H. (1996). Pseudomonas rhodesiae sp. nov., a new species isolated from natural mineral waters. Syst Appl Microbiol 19, 600-607.

Crosa, J. H., Brenner, D. J. \& Falkow, S. (1973). Use of a singlestrand specific nuclease for analysis of bacterial and plasmid deoxyribonucleic acid homo- and hetero-duplexes. $J$ Bacteriol 115, 904-911.

Dabboussi, F., Hamze, M., Elomari, M., Verhille, S., Baida, N., Izard, D. \& Leclerc, H. (1998). A numerical study of fluorescent Pseudomonas strains isolated from three Lebanese spring waters. $J$ Eur Hydrol 28, 325-338.

De Ley, J. (1970). Re-examination of the association between melting point, buoyant density, and chemical base composition of deoxyribonucleic acid. $J$ Bacteriol 101, 737-754.

De Vos, P. \& De Ley, J. (1983). Intra- and intergeneric similarities of Pseudomonas and Xanthomonas ribosomal ribonucleic acid cistrons. Int J Syst Bacteriol 33, 487-509.

De Vos, P., Kersters, K., Falsen, E., Pot, B., Gillis, M., Segers, P. \& De Ley, J. (1985). Comamonas David and Park 1962 gen. nov., nom. rev. emend., and Comamonas terrigena Hugh $1962 \mathrm{sp}$. nov., nom. rev. Int J Syst Bacteriol 35, 443-453.

Edwards, U., Rogall, T., Blöcker, H., Emde, M. \& Böttger, E. (1989). Isolation and direct complete nucleotide determination of entire genes. Characterization of a gene coding for $16 \mathrm{~S}$ ribosomal RNA. Nucleic Acids Res 17, 7843-7853.

Elomari, M., Coroler, L., Hoste, B., Gillis, M., Izard, D. \& Leclerc, H. (1996). DNA relatedness among Pseudomonas strains isolated from natural mineral waters and proposal of Pseudomonas veronii sp. nov. Int J Syst Bacteriol 46, 1138-1144.

Elomari, M., Coroler, L., Verhille, S., Izard, D. \& Leclerc, H. (1997). Pseudomonas monteilii sp. nov., isolated from clinical specimens. Int J Syst Bacteriol 47, 846-852.

Felsenstein, J. (1985). Confidence limits on phylogenies: an approach using the bootstrap. Evolution 39, 783-791.

Gillis, M., Van Van, T., Bardin, R. \& 7 other authors (1995). Polyphasic taxonomy in the genus Burkholderia leading to an emended description of the genus and proposition of Burkholderia vietnamiensis sp. nov., for $\mathrm{N}_{2}$-fixing isolates from rice in Vietnam. Int J Syst Bacteriol 45, 274-289.

Grimont, P. A. D., Popoff, M. Y., Grimont, F., Coynault, C. \& Lemelin, M. (1980). Reproducibility and correlation study of three deoxyribonucleic acid hybridization procedures. Curr Microbiol 4, 325-330.

Hoeniger, J. F. M. (1965). Development of flagella by Proteus mirabilis. J Gen Microbiol 40, 29-33.

Kersters, K., Ludwig, W., Vancanneyt, M., De Vos, P., Gillis, M. \& Schleifer, K. H. (1996). Recent changes in the classification of the pseudomonads: an overview. Syst Appl Microbiol 19, 465-477.

Kimura, M. (1980). A simple method for estimating evolutionary rates of base substitutions through comparative studies of nucleotide sequences. $J$ Mol Evol 16, 111-120.

Lane, D. J. (1991). 16S/23S sequencing. In Nucleic Acid Techniques in Bacterial Systematics, p. 115. Edited by E. Stackebrandt \& M. Goodfellow. Chichester: Wiley.

Leclerc, H. \& Guillot, E. (1992). Etude de la flore bactérienne de deux sources d'eaux minérales naturelles; caractérisation par les profils de restriction des gènes codant pour les ARN ribo- somaux; spécificité et stabilité biologique. Bull Acad Natl Med 176, 1491-1504.

Molin, G. \& Ternström, A. (1982). Numerical taxonomy of the psychrophilic pseudomonads. J Gen Microbiol 128, 1249-1264.

Moore, E. R. B., Mau, M., Arnsceidt, A., BÖttger, E. C., Hutson, R. A., Collins, M. D., Van De Peer, Y., De Wachter, R. \& Timmis, K. N. (1996). The determination and comparison of the $16 \mathrm{~S}$ rRNA gene sequences of species of the genus Pseudomonas (sensu stricto) and estimation of the natural intrageneric relationships. Syst Appl Microbiol 19, 478-492.

Palleroni, N. J. (1984). Genus I. Pseudomonas Migula 1894 , $237^{\mathrm{AL}}$ (Nom. cons. Opin. 5, Jud. Comm. 1952, 237). In Bergey's Manual of Systematic Bacteriology, vol. 1, pp. 141-199. Edited by N. R. Krieg \& J. G. Holt. Baltimore: Williams \& Wilkins.

Palleroni, N. J. \& Bradbury, J. F. (1993). Stenotrophomonas, a new bacterial genus for Xanthomonas maltophilia (Hugh 1980) Swings et al., 1983. Int J Syst Bacteriol 43, 606-609.

Palleroni, N. J., Kunisawa, R., Contopoulou, R. \& Doudoroff, M. (1973). Nucleic acid homologies in the genus Pseudomonas. Int J Syst Bacteriol 23, 333-339.

Saitou, N. \& Nei, M. (1987). The neighbor-joining method: a new method for reconstructing phylogenetic trees. Mol Biol Evol 4, 406-425.

Segers, P., Vancanneyt, M., Pot, B., Torck, U., Hoste, B. Dewettinck, D., Falsen, E., Kersters, K. \& De Vos, P. (1994). Classification of Pseudomonas diminuta Leifson and Hugh 1954 and Pseudomonas vesicularis Büsing, Döll, and Freytag 1953 in Brevundimonas gen. nov. as Brevundimonas diminuta comb. nov., and Brevundimonas vesicularis comb. nov., respectively Int J Syst Bacteriol 44, 499-510.

Swings, J., De Vos, P., Van Den Mooter, M. \& De Ley, J. (1983). Transfer of Pseudomonas maltophilia Hugh 1981 to the genus Xanthomonas as Xanthomonas maltophilia (Hugh 1981) comb. nov. Int J Syst Bacteriol 30, 547-556.

Thompson, J. D., Higgins, D. G. \& Gibson, T. J. (1994). CLUSTAL $\mathrm{W}$ : improving the sensitivity of progressive multiple sequence alignment through sequence weighting, position-specific gap penalties and weight matrix choice. Nucleic Acids Res 22 , $4673-4680$

Urakami, T., Ito-Yoshida, C., Araki, H., Kijima, T., Suzuki, K. I. \& Komagata, K. (1994). Transfer of Pseudomonas plantarii and Pseudomonas glumae to Burkholderia as Burkholderia spp., and description of Burkholderia vandii sp. nov. Int $J$ Syst Bacteriol 44, 235-245.

Wayne, L. G., Brenner, D. J., Colwell, R. R. \& 9 other authors (1987). International Committee on Systematic Bacteriology. Report of the ad hoc committee on reconciliation of approaches to bacterial systematics. Int J Syst Bacteriol 37, 463-464.

Willems, A., Busse, J., Goor, M., Pot, B., Falsen, E., Jantzen, E., Hoste, B., Gillis, M., Kersters, K., Auling, G. \& De Ley, J. (1989). Hydrogenophaga, a new genus of hydrogen-oxidizing bacteria that includes Hydrogenophaga flava comb. nov., (formerly Pseudomonas flava), Hydrogenophaga palleroni, (formerly Pseudomonas palleroni), Hydrogenophaga pseudoflava (formerly Pseudomonas pseudoflava and 'Pseudomonas carboxydoflava'), and Hydrogenophaga taeniospiralis (formerly Pseudomonas taeniospiralis). Int J Syst Bacteriol 39, 319-333.

Willems, A., Falsen, E., Pot, B., Jantzen, E., Hoste, B., Vandamme, P., Gillis, M., Kersters, K. \& De Ley, J. (1990). Acidovorax, a new genus for Pseudomonas facilis, Pseudomonas delafieldii, EF group 13, EF group 16, and several clinical isolates, with the 
species Acidovorax facilis comb. nov., Acidovorax delafieldii comb. nov., and Acidovorax temperans sp. nov. Int J Syst Bacteriol 40, 384-398.

Willems, A., De Ley, J., Gillis, M. \& Kersters, K. (1991). Comamonadaceae, a new family encompassing the acidovorans rRNA complex, including Variovorax paradoxus gen. nov., comb. nov., for Alcaligenes paradoxus (Davis 1969). Int J Syst Bacteriol 41, 445-450.

Willems, A., Goor, M., Thielemans, S., Gillis, M. \& Kersters, K. (1992). Transfer of several phytopathogenic Pseudomonas species to Acidovorax as Acidovorax avenae subsp. avenae subsp. nov., comb. nov., Acidovorax avenae subsp. citrulli, Acidovorax avenae subsp. cattleyae, and Acidovorax konjaci. Int J Syst Bacteriol 42, 107-119.
Woese, C. R. (1987). Bacterial evolution. Microbiol Rev 51, 221-271.

Yabuuchi, E., Kosako, Y., Oyaizu, H., Yano, I., Hotta, H., Hashimoto, Y., Ezaki, T. \& Arakawa, M. (1992). Proposal of Burkholderia gen. nov. and transfer of seven species of the genus Pseudomonas homology group II to the new genus, with the type species Burkholderia cepacia (Palleroni and Holmes 1981) comb. nov. Microbiol Immunol 36, 1251-1275.

Yabuuchi, E., Kosako, Y., Yano, I., Hotta, H. \& Nishiuchi, Y. (1995). Transfer of two Burkholderia and an Alcaligenes species to Ralstonia gen. nov.: proposal of Ralstonia pickettii (Ralston, Palleroni and Doudoroff 1973) comb. nov., Ralstonia solanacearum (Smith 1896) comb. nov. and Ralstonia eutropha (Davis 1969) comb. nov. Microbiol Immunol 39, 897-904. 